\title{
BIREFRINGENCE, ISOTROPIC POINTS, AND OPTICAL FILTERS BASED ON $\mathrm{CuGa}_{x} \mathrm{Al}_{1-x} \mathrm{Se}(\mathrm{S})_{2}$ CRYSTALS
}

\author{
Alisa Mașnic ${ }^{1}$ and Veaceslav Ursaki ${ }^{2}$ \\ ${ }^{I}$ Department of Radioelectronics, Technical University of Moldova, bulvd. Stefan cel Mare si \\ Sfant 168, Chisinau, MD-2004 Republic of Moldova \\ ${ }^{2}$ National Center for Materials Study and Testing, Technical University of Moldova, bulvd. \\ Stefan cel Mare si Sfant 168, Chisinau, MD-2004 Republic of Moldova \\ E-mail:vvursaki@gmail.com
}

(Received, November 1, 2021)

https://doi.org/10.53081/mjps.2021.20-2.04

CZU:538.9+535.39+532.783

\begin{abstract}
A brief review on birefringence and optical filters based on $\mathrm{CuGa}_{\mathrm{x}} \mathrm{Al}_{1-\mathrm{x}} \mathrm{S}_{2}$ and $\mathrm{CuGa}_{\mathrm{x}} \mathrm{Al}_{1-}$ ${ }_{x} \mathrm{Se}_{2}$ crystals is given in this paper. Two types of isotropic points are analyzed; one of them refers to a case when the wavelength at which the ordinary and extraordinary refractive indices are equal is situated near the absorption edge, while in the second case the isotropic wavelength is in the region of crystal transparency. It is shown that both of them can be used for the development of band-pass and band-reject filters. The possibility of adjusting the spectral position of an isotropic point by changing the chemical composition of a solid solution is illustrated, and the applicability of $\mathrm{CuGa}_{\mathrm{x}} \mathrm{Al}_{1-\mathrm{x}} \mathrm{S}_{2}$ and $\mathrm{CuGa}_{\mathrm{x}} \mathrm{Al}_{1-\mathrm{x}} \mathrm{Se}_{2}$ for adjusting the isotropic point to most of $\mathrm{Ar}^{+}$, $\mathrm{Kr}^{+}, \mathrm{He}-\mathrm{Ne}$, and $\mathrm{He}-\mathrm{Cd}$ gas lasers lines, as well as to semiconductor lasers, is revealed.

Keywords: solid solutions, refractive index, birefringence, isotropic wavelength, band-pass filter, band-reject filter

\section{Rezumat}

Această lucrare prezintă o scurtă analiză a proprietăților de birefringență și a filtrelor optice elaborate în baza cristalelor de $\mathrm{CuGa}_{\mathrm{x}} \mathrm{Al}_{1-\mathrm{x}} \mathrm{S}_{2} \mathrm{Ş}_{1} \mathrm{CuGa}_{\mathrm{x}} \mathrm{Al}_{1-\mathrm{x}} \mathrm{Se}_{2}$. Sunt analizate două tipuri de puncte izotrope. Primul tip se referă la cazul când lungimea de undă a punctului izotrop, adică lungimea de undă, la care valorile indicilor de refracție ordinari și extraordinari sunt egale, este situată în apropierea marginii de absorbție. Al doilea tip de puncte izotrope sunt cele cu lungimea de undă din regiunea de transparență a cristalului. Se arată că ambele tipuri de puncte izotrope pot fi utilizate la elaborarea filtrelor optice trece-bandă și stop-bandă. Este ilustrată posibilitatea de a ajusta poziția spectrală a punctului izotrop prin schimbarea compoziției chimice a soluțiilor solide și este evidențiată aplicabilitatea soluțiilor solide $\mathrm{CuGa}_{\mathrm{x}} \mathrm{Al}_{1-\mathrm{XS}} \mathrm{S}_{2} \mathrm{Ş}_{1} \mathrm{CuGa}_{\mathrm{x}} \mathrm{Al}_{1-\mathrm{XSe}} \mathrm{Se}_{2}$ pentru ajustarea punctului izotrop la majoritatea lungimilor de undă a liniilor laserelor cu gaze $\mathrm{Ar}^{+}, \mathrm{Kr}^{+}, \mathrm{He}-\mathrm{Ne}$ și He-Cd, precum și a laserelor cu semiconductori.

Cuvinte cheie: soluții solide, indice de refracție, birefringență, lungime de undă izotropă, filtru trece-bandă, filtru stop-bandă
\end{abstract}




\section{Introduction}

$\mathrm{A}^{\mathrm{I}} \mathrm{B}^{\mathrm{III}} \mathrm{C}^{\mathrm{VI}}{ }_{2}$ compounds are considered as an extension of $\mathrm{A}^{\mathrm{II}} \mathrm{B}^{\mathrm{VI}}$ materials with a zincblende structure from the point of view of their crystalline structure, they being an alternating packing of two zincblende cells with $\mathrm{A}^{\mathrm{I}}$ and $\mathrm{B}^{\mathrm{III}}$ cations instead of $\mathrm{A}^{\mathrm{II}}$ cations. While $\mathrm{A}^{\mathrm{II}} \mathrm{B}^{\mathrm{VI}}$ materials are widely used in electronic, optoelectronic, and photonic devices [1,2], the diversity of $\mathrm{A}^{\mathrm{I}} \mathrm{B}^{\mathrm{III}} \mathrm{C}_{2}^{\mathrm{VI}}$ compounds extends even further the area of practical applications. The substitution of $\mathrm{A}^{\mathrm{II}}$ cations by $\mathrm{A}^{\mathrm{I}}$ and $\mathrm{B}^{\mathrm{III}}$ ones results in the formation of a non-centrosymmetric structure with anisotropic optical properties. Particularly, birefringence inherent in these materials is of particular interest by making them suitable for the development of optical filters [3-10]. In addition, narrow bandgap $\mathrm{CuIn}_{1-x} \mathrm{Ga}_{x} \mathrm{Se}_{2}$ materials are commonly used in photovoltaic cells [11, 12], while the application of wide bandgap compounds, such as $\mathrm{AgGaS}_{2}$ and $\mathrm{AgGaSe}_{2}$ was demonstrated in nonlinear optics [13-15]. Nanostructured $\mathrm{A}^{\mathrm{I}} \mathrm{B}^{\mathrm{III}} \mathrm{C}^{\mathrm{VI}}{ }_{2}$ compounds are used in light emitting devices $[16,17]$ and photocatalysis $[18,19]$.

The existence of accidental isotropic points, at which the ordinary $\left(n_{\mathrm{o}}\right)$ and extraordinary $\left(n_{\mathrm{e}}\right)$ refractive indices have equal values, is a necessary condition for anisotropic crystals to be suitable for fabrication of band-reject or band-pass optical filters. Particularly, band-reject optical filters are fairly useful for applications in Raman spectroscopy, because they allow measuring Raman scattering at frequencies extremely close to the excitation laser line. Therefore, one can perform Raman spectroscopy studies with ordinary monochromators instead of expensive double or triple monochromators. Band-reject filters based on uniaxial optically active $\mathrm{AgGaSe}_{2}$ crystals were proposed for Raman spectroscopy with AlGaAs semiconductor lasers [7-10].

In this paper, birefringence and existence of isotropic wavelengths in $\mathrm{CuGa}_{x} \mathrm{Al}_{1-\mathrm{x}} \mathrm{S}_{2}$ and $\mathrm{CuGa}_{\mathrm{x}} \mathrm{Al}_{1-\mathrm{X}} \mathrm{Se}_{2}$ crystals are explored for the purpose of developing optical filters.

\section{Sample Preparation and Experimental Details}

Birefringent and optically active $\mathrm{CuGa}_{x} \mathrm{Al}_{1-\mathrm{x}} \mathrm{Se}(\mathrm{S})_{2}$ crystals in the form of rectangular prisms with mirror-like surfaces around $1 \times 1 \mathrm{~cm}^{2}$ were grown by chemical vapor transport. The prisms were crystallographically oriented with the (100) faces and with the $c$-axis in this plane. Platelets with thicknesses of 4-270 $\mu \mathrm{m}$ were cut from these bulk crystals. The rectangular platelets were mounted between a polarizer and an analyzer (Glan-Thomson polarization prisms) as shown in Fig. 1.
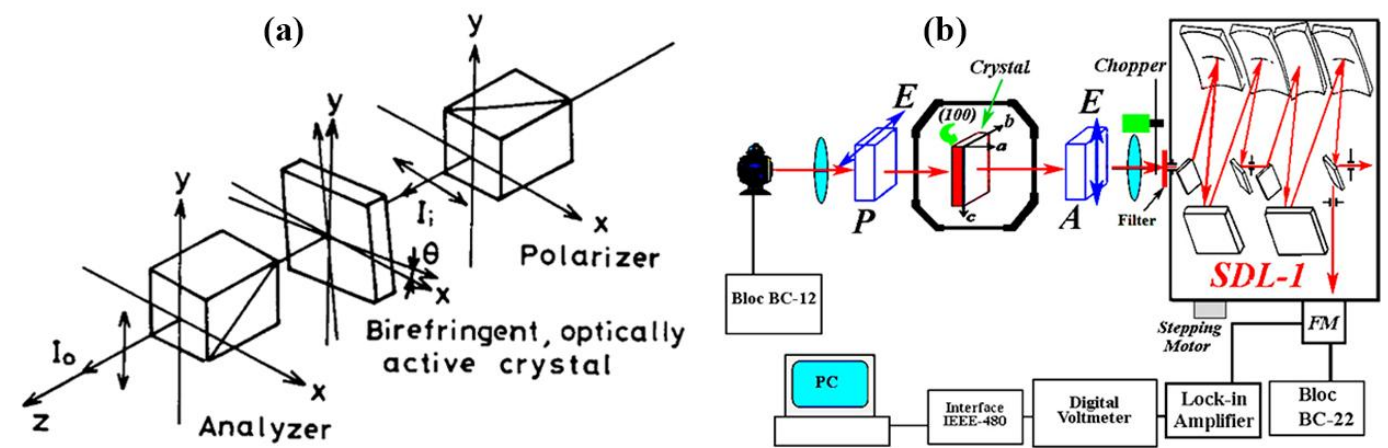

Fig. 1. (a) Optical arrangement and (b) scheme of the experimental setup used for studying the characteristics of optical filters. 
The light propagation direction was along the $z$-axis, while the $x$ and $y$ coordinates of the optical system corresponded to the polarizer and analyzer axes. Therefore, the incident (100) face of the crystal platelet was perpendicular to the $z$-axis, while the principal axes of the dielectric tensor form a $\Theta$ angle with the $x$ and $y$ axes.

The ratio of the light intensity behind the analyzer $I_{\mathrm{o}}$ to the intensity of the light passed through the polarizer $I_{i}$ in a system with the above described geometry is given by [20]

$$
\begin{aligned}
& I_{\downarrow} \mathbf{0} / I_{\downarrow} i=E((, \theta) \cdot R(\mathrm{O}), \\
& E\left((, \theta)=\frac{\delta_{b}^{2} \sin ^{2} 2 \theta+\delta_{g}^{2}}{\delta_{b}^{2}+\delta_{g}^{2}},\right. \\
& R\left(0=\llbracket \sin \rrbracket^{\boldsymbol{\top}_{2}} \quad \llbracket\left(\delta_{\downarrow} b^{\boldsymbol{\top}_{2}}+\delta_{\downarrow} g^{\uparrow} 2\right) \rrbracket^{\dagger}(1 / 2) / 2,\right.
\end{aligned}
$$

where $\delta_{b}=(2 \pi / \lambda) l \cdot \Delta n$ and $\delta_{g}=(2 \pi / \lambda) l(G / \bar{n})$ are retardations due to birefingence and optical activity, respectively; $\Delta n$ is the birefringence, $G$ is the optical gyration, $\bar{n}$ is the average refractive index, and $\Delta n$ is the birefringence. $E(\lambda, \Theta)$ represents an envelope of $\left(I_{0} / I_{i}\right)$, it being much less sensitive to the wavelength than $R(\lambda)$. Equation (2) takes the following form, when the $\Theta$ angle is zero:

$$
E\left((, 0)=\frac{\delta_{g}^{2}}{\delta_{b}^{2}+\delta_{g}^{2}} .\right.
$$

The spectral dependence of $E(\lambda, \Theta)$ will have characteristics of a band pass filter with the central wavelength at $\lambda_{0}$, since $\Delta n$ is zero at the accidental isotropic wavelength $\lambda_{0}$ and the $\Delta n$ value rapidly increases toward both sides of the isotropic point. The $E(\lambda \Theta)$ value will be equal to unity when $\Delta n$ and $\delta_{\mathrm{b}}$ are zero; $R(\lambda)$ will also be equal to unity at the isotropic wavelength, so that the ration of $\left(I_{\mathrm{o}} / I_{i}\right)$ will reach a maximum. These conditions are fulfilled when thickness $l$ is chosen so that $\delta_{g}$ acquires a value of $(2 m+1)$, where $m=0,1,2,3 \ldots$

The optical spectra were measured at room temperature using a setup based on a SDL-1 double spectrometer with a scheme shown in Fig. 2.

\section{Birefringence, Isotropic Points, and Optical Filters}

The position of the isotropic point in $\mathrm{CuGa}_{\mathrm{x}} \mathrm{Al}_{1-\mathrm{x}} \mathrm{Se}(\mathrm{S})_{2}$ solutions was determined from measurements of interference bands with two polarizers in the polarizer-crystal-analyzer configuration. The difference in ordinary and extraordinary refractive indices can be determined by registering the interference in optical transmission or reflectance spectra of thin crystals measured separately in $E \| c$ and $E \perp c$ polarizations. Interference of light waves reflected from mirror-like plan-parallel surfaces occurs upon the propagation of light through thin crystals according to the following condition:

$$
2 \pi n d \lambda^{-1}=\mathrm{N} \pi+\pi / 2
$$

where $n$ is the refractive index of the crystal, $d$ is the crystal thickness, and $N$ is the number of the interference band. By measuring the wavelengths of two nearest maxima (minima) $\lambda_{a}$ and $\lambda_{b}$ in the interference spectrum in a crystal with the known thickness $d$, one can determine the refractive indices:

$$
\begin{aligned}
& n_{\|}=1 / 2 d\left(\lambda_{\mathrm{a} \|}\left\|^{-1}-\lambda_{\mathrm{b}}\right\|^{-1}\right) \text { for the } E \| c \text { polarization, } \\
& n_{\perp}=1 / 2 d\left(\lambda_{\mathrm{a} \perp}{ }^{-1}-\lambda_{\mathrm{b} \perp}{ }^{-1}\right) \text { for the } E \perp c \text { polarization. }
\end{aligned}
$$

However, measurement of interference spectra in the polarizer-crystal-analyzer configuration 
proved to be a more sensitive and efficient method for the determination of birefringence in crystals $\left(\Delta n=n_{\mathrm{o}}-n_{\mathrm{e}}\right)$ and for the determination of isotropic wavelengths.

Figure $2 \mathrm{a}$ shows transmission spectra of $\mathrm{CuGa}_{\mathrm{x}} \mathrm{Al}_{1-\mathrm{x}} \mathrm{Se}_{2}$ crystals with three different compositions $(x=0.2,0.5,1.0)$ placed between crossed polarizers. A series of interference bands is observed in the spectra; the distance between them is determined by the crystal birefringence $\Delta n=n_{\mathrm{o}}-n_{\mathrm{e}}$. The interference band near the isotropic point $(580 \mathrm{~nm}$ for $x=0.2,670 \mathrm{~nm}$ for $x=0.5$, and $810 \mathrm{~nm}$ for $x=1.0$ ) exhibits an increase in transmission compared with that of the neighbors.
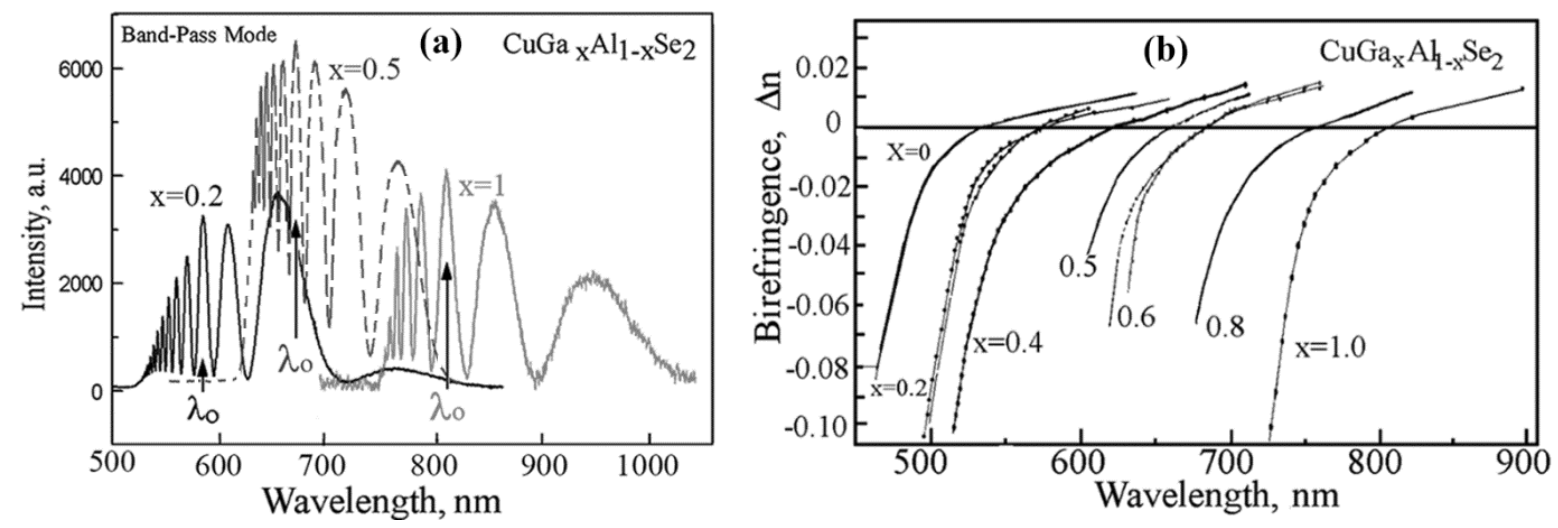

Fig. 2. (a) Optical transmittance spectra of $\mathrm{CuGa}_{\mathrm{x}} \mathrm{Al}_{1-\mathrm{x}} \mathrm{Se}$ crystals with $x$ value of $0.2,0.5$, and 1.0 and with thickness of 109,145 , and $150 \mu \mathrm{m}$, respectively, measured at room temperature when placed between two crossed polarizers; (b) spectral dependence of birefringence in $\mathrm{CuGa}_{x} \mathrm{Al}_{1-x} \mathrm{Se}_{2}$ solid solutions.

The spectral dependence of birefringence for $\mathrm{CuGa}_{x} \mathrm{Al}_{1-x} \mathrm{Se}_{2}$ solid solutions deduced from analysis of the transmission spectra of crystals with different compositions and thicknesses is shown in Fig. 2b. The wavelength at which the curves intersect the abscissa axis corresponds to the isotropic point of the crystal with a respective composition.

Using the data from Fig. $2 b$, the dependence of isotropic wavelength of $\mathrm{CuGa}_{x} \mathrm{Al}_{1-x} \mathrm{Se}_{2}$ solid solutions was plotted as a function of composition $x$, which is shown in Fig. 3a. The dependence of the bandgap on the composition at room temperatures is also shown in Fig. 3a. It is evident from Fig. 3a that the dependence of the isotropic point follows the dependence of the bandgap. This behavior is characteristic of isotropic points situated near the absorption edge of crystals. These isotropic points are determined by the intrinsic properties of crystals; they are insignificantly affected by extrinsic factors, in particular, contamination of crystals with impurities.

A similar behavior is characteristic of the isotropic point in $\mathrm{CuGa}_{x} \mathrm{Al}_{1-x} \mathrm{~S}_{2}$ solid solutions, as shown in Fig. 3b. The distance between the absorption edge (bandgap) and the isotropic point $\lambda_{0}$ in $\mathrm{CuGa}_{x} \mathrm{Al}_{1-x} \mathrm{Se}_{2}$ solid solutions decreases from $380 \mathrm{meV}[\Delta \mathrm{E}=2.60 \mathrm{eV}(475 \mathrm{~nm})-2.23 \mathrm{eV}$ $(540 \mathrm{~nm})]$ for $\mathrm{CuAlSe}_{2}$, to $180 \mathrm{meV}[\Delta \mathrm{E}=1.71 \mathrm{eV}(725 \mathrm{~nm})-1.53 \mathrm{eV}(810 \mathrm{~nm})]$ for $\mathrm{CuGaSe}_{2}$. In $\mathrm{CuGa}_{x} \mathrm{Al}_{1-x} \mathrm{~S}_{2}$ solid solutions, this energetic distance decreases from $270 \mathrm{meV}[\Delta \mathrm{E}=3.49 \mathrm{eV}$ $(355 \mathrm{~nm})-3.22 \mathrm{eV}(385 \mathrm{~nm})]$ for $\mathrm{CuAlS}_{2}$, to $120 \mathrm{meV}[\Delta \mathrm{E}=2.48 \mathrm{eV}(500 \mathrm{~nm})-2.36 \mathrm{eV}$ $(526 \mathrm{~nm})]$ for $\mathrm{CuGaS}_{2}$. 

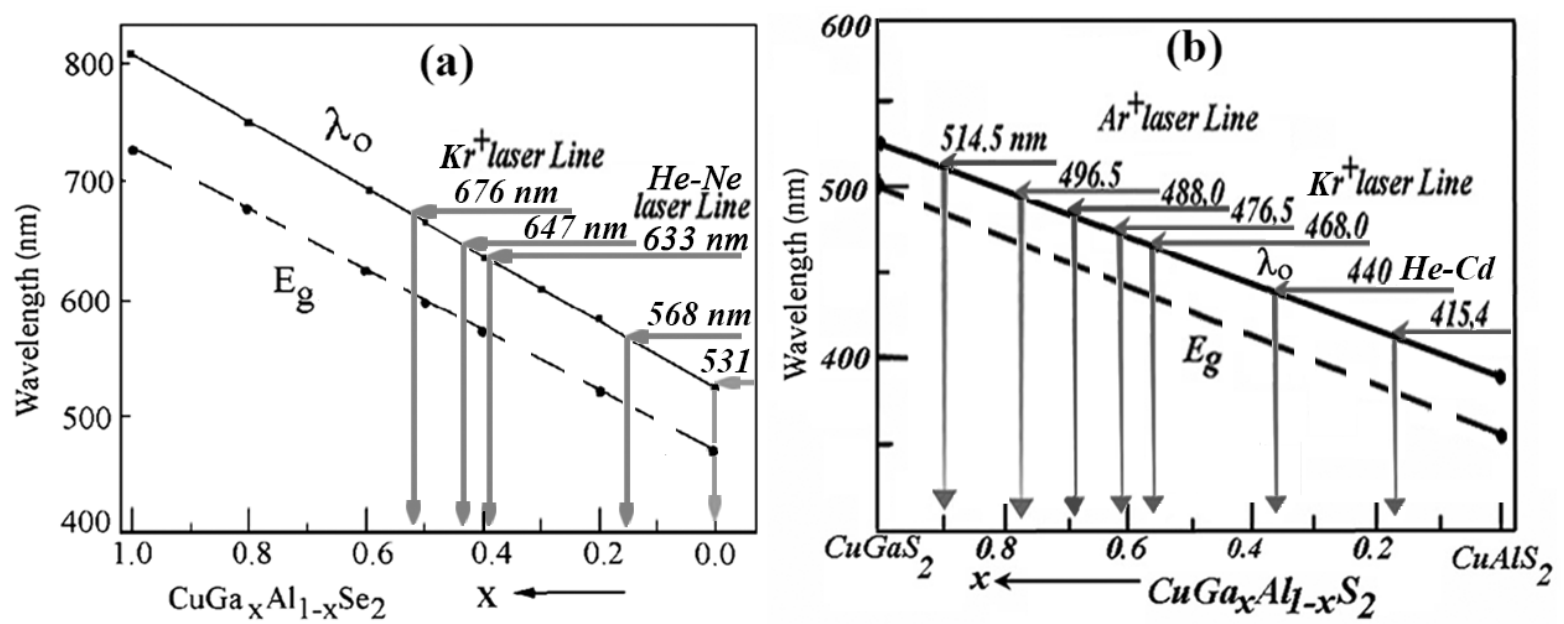

Fig. 3. Dependence of the spectral position of the isotropic wavelength with respect to the bandgap as a function of the composition $x$ of (a) $\mathrm{CuGa}_{\mathrm{x}} \mathrm{Al}_{1-\mathrm{x}} \mathrm{Se}_{2}$ and (b) $\mathrm{CuGa}_{\mathrm{x}} \mathrm{Al}_{1-\mathrm{x}} \mathrm{S}_{2}$ solid solutions.

In addition to the isotropic point $\left(\lambda_{0}\right)$ situated near the absorption edge, another isotropic point $\left(\lambda_{01}\right)$ was observed in the region of transparence of $\mathrm{CuAlS}_{2}$ crystals at $535 \mathrm{~nm}$ and at 639 $\mathrm{nm}$ in $\mathrm{CuGaS}_{2}$ crystals, as shown in Fig. 4. It is evident from this figure that the crystals exhibit negative birefringence $\left(n_{\mathrm{e}}-n_{\mathrm{o}}\right)>0$ at wavelengths longer than $\lambda_{0}$ and shorter than $\lambda_{01}$, while the birefringence is positive in the spectral range in between these isotropic points $\lambda_{01}<\lambda<\lambda_{0}$.
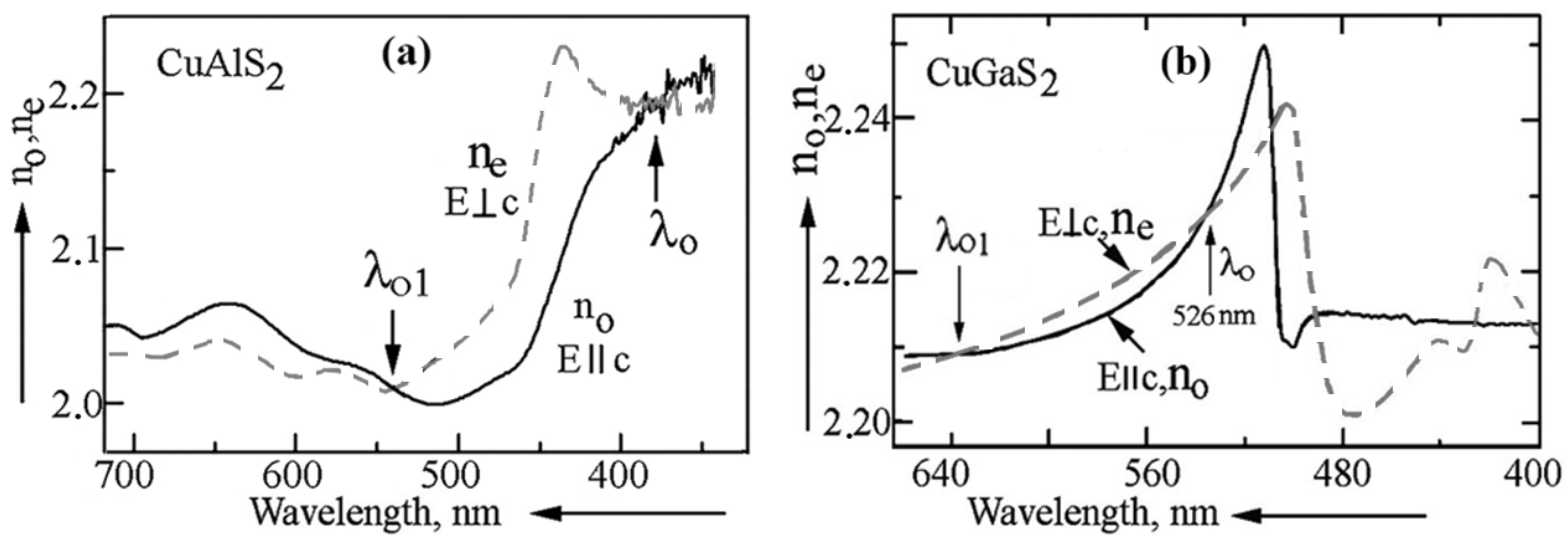

Fig. 4. Spectral dependences of the ordinary and extraordinary refractive indices calculated from the reflection spectra of (a) $\mathrm{CuAlS}_{2}$ crystals with a thickness of $223 \mu \mathrm{m}$ and (b) $\mathrm{CuGaS}_{2}$ crystals with a thickness of $4.5 \mu \mathrm{m}$.

It should be noted that the spectral position of the isotropic point $\lambda_{01}$, as well as the birefringence value $\left(n_{\mathrm{e}}-n_{\mathrm{o}}\right)$, is different in crystals with different thicknesses, while the isotropic point $\lambda_{0}$ is less sensitive to the crystal thickness. This observation is attributed to the fact that the spectral position of an isotropic point is affected not only by the intrinsic gyroscopy, but also by other factors, in particular, the impurity concentration, which can be different depending on the 
technological conditions for crystal growth. It is evident that the intrinsic properties are not significantly affected by the crystal growth conditions. Accordingly, the spectral position of the isotropic point $\lambda_{0}$ does not significantly differ in crystals with different thicknesses unlike the isotropic point $\lambda_{01}$.

The possibility of adjusting the spectral position of an isotropic point by changing the chemical composition of a solid solution, as shown in Fig. 3, is extremely important for the development of optical filters. Band-pass and band-reject filters are especially important for Raman spectroscopy, as noted above, because they can have an extremely narrow spectral band. This is particularly important in the case of using semiconductor lasers for Raman scattering excitation, because they are less expensive than gas lasers, solid state lasers, or lasers on dyes. A narrow spectral band of the optical filter is important, because semiconductor lasers have a larger emission band.

To use semiconductor crystals in these applications of optical filters, it is necessary to the provide the coincidence of the spectral band of the filter with the emission band of the laser. The possibilities of using $\mathrm{CuGa}_{x} \mathrm{Al}_{1-x} \mathrm{Se}_{2}$ and $\mathrm{CuGa}_{x} \mathrm{Al}_{1-x} \mathrm{~S}_{2}$ solid solutions in these applications are shown in Figs. $3 \mathrm{a}$ and $3 \mathrm{~b}$, respectively. It is evident from Fig. 3 that $\mathrm{CuGa}_{x} \mathrm{Al}_{1-x} \mathrm{Se}_{2}$ solid solutions with the $\mathrm{CuGa}_{0.4} \mathrm{Al}_{0.6} \mathrm{Se}_{2}$ composition can be used in Raman spectroscopy in combination with a $\mathrm{He}-\mathrm{Ne}$ laser at a radiation wavelength of $632.8 \mathrm{~nm}$. Solid solutions of $\mathrm{CuGa}_{0.15} \mathrm{Al}_{0.85} \mathrm{Se}_{2}, \mathrm{CuGa}_{0.43} \mathrm{Al}_{0.57} \mathrm{Se}_{2}$, and $\mathrm{CuGa}_{0.55} \mathrm{Al}_{0.45} \mathrm{Se}_{2}$ can be used for $\mathrm{Kr}^{+}$laser lines of 568, 647, and $676 \mathrm{~nm}$, respectively, while $\mathrm{CuGa}_{x} \mathrm{Al}_{1-x} \mathrm{~S}_{2}$ solid solutions with the composition in a range of 0.6-0.9 are suitable for using with $\mathrm{Ar}^{+}$laser lines of 476.5, 488, 496.5, and $514.5 \mathrm{~nm}$. Crystals of $\mathrm{CuAlSe} 2$ correspond to the $\mathrm{Kr}^{+}$laser line of $531 \mathrm{~nm}$, while $\mathrm{CuGa}_{\mathrm{x}} \mathrm{Al}_{1-\mathrm{x}} \mathrm{S}_{2}$ solid solutions with composition in a range of $0.1-0.6$ are suitable for $\mathrm{Kr}^{+}$laser lines of 406.7, 413.1, 415.4, 468, 476, and $482 \mathrm{~nm}$.

The isotropic point $\lambda_{01}$ at $640 \mathrm{~nm}$ in $\mathrm{CuGaS}_{2}$ crystals is also near the $632.8 \mathrm{~nm}$ line of the $\mathrm{He}-\mathrm{Ne}$ laser, so that adjustment to this laser line can be done by some doping of $\mathrm{CuGaS}_{2}$ crystals, since the isotropic point $\lambda_{01}$ is shifted in crystals grown under different technological conditions, as discussed above. The spectral position of the $\lambda_{01}$ in $\mathrm{CuAlS}_{2}$ crystals varies in a range of $535-485 \mathrm{~nm}$. Therefore, this isotropic point can be used for adjusting to the neodymium laser line at $532 \mathrm{~nm}$ or to lines of the $\mathrm{Ar}^{+}$laser. At the same time, $\mathrm{CuGa}_{x} \mathrm{Al}_{1-x} \mathrm{Se}_{2}$ solid solutions can be used in combination with semiconductor lasers with emission wavelengths in a range of 530-810 $\mathrm{nm}$, while $\mathrm{CuGa}_{x} \mathrm{Al}_{1-x} \mathrm{~S}_{2}$ solid solutions are suitable for lasers with emission wavelengths in a range of 380-640 nm.

Coupling between ordinary and extraordinary modes occurs at isotropic wavelength in $\mathrm{CuAl}_{x} \mathrm{Ga}_{1-x} \mathrm{Se}_{2}$ and $\mathrm{CuAl}_{x} \mathrm{Ga}_{1-x} \mathrm{~S}_{2}$ solid solutions due to the natural optical activity inherent in these materials. The condition for phase adjustment and coupling of modes should be fulfilled to provide energy transfer between the modes. The optical activity of these solid solutions is provided by the effects of spatial dispersion and inter-band electronic transitions in the case of isotropic points situated near the absorption edge and by the effects of impurity absorption in the case of isotropic points situated in the crystal transparence region. In the second case, the spectral position of the isotropic point is affected by the impurity concentration, in particular, unintentional doping; the concentration can vary with a change in the technological conditions for crystal growth, in particular, the degree of purity of the precursor.

Optical filters operating at the isotropic point $\lambda_{0}$ were based on $\mathrm{CuAlSe}_{2}, \mathrm{CuGaSe}_{2}$, $\mathrm{CuAlS}_{2}$, and $\mathrm{CuAlS}_{2}$ crystals. A set of band-reject and pass-band filters based on $\mathrm{CuAl}(\mathrm{Ga}) \mathrm{Se}(\mathrm{S})_{2}$ crystals placed between parallel and crossed polarizers is shown in Fig. 5. 
These filters based on crystals with a thickness of 220-270 $\mu \mathrm{m}$ have a band width of a few angstroms. Comb filters with band widths of a few nanometers can be based on thinner crystals. The contrast of an optical filter is determined by the ratio of the transmission in the main maximum to the transmission in lateral maxima. The lower the value of the transmission in the lateral maximum, the better the filter contrast. The value of the contrast in pass-band and band-reject filters is around 20.
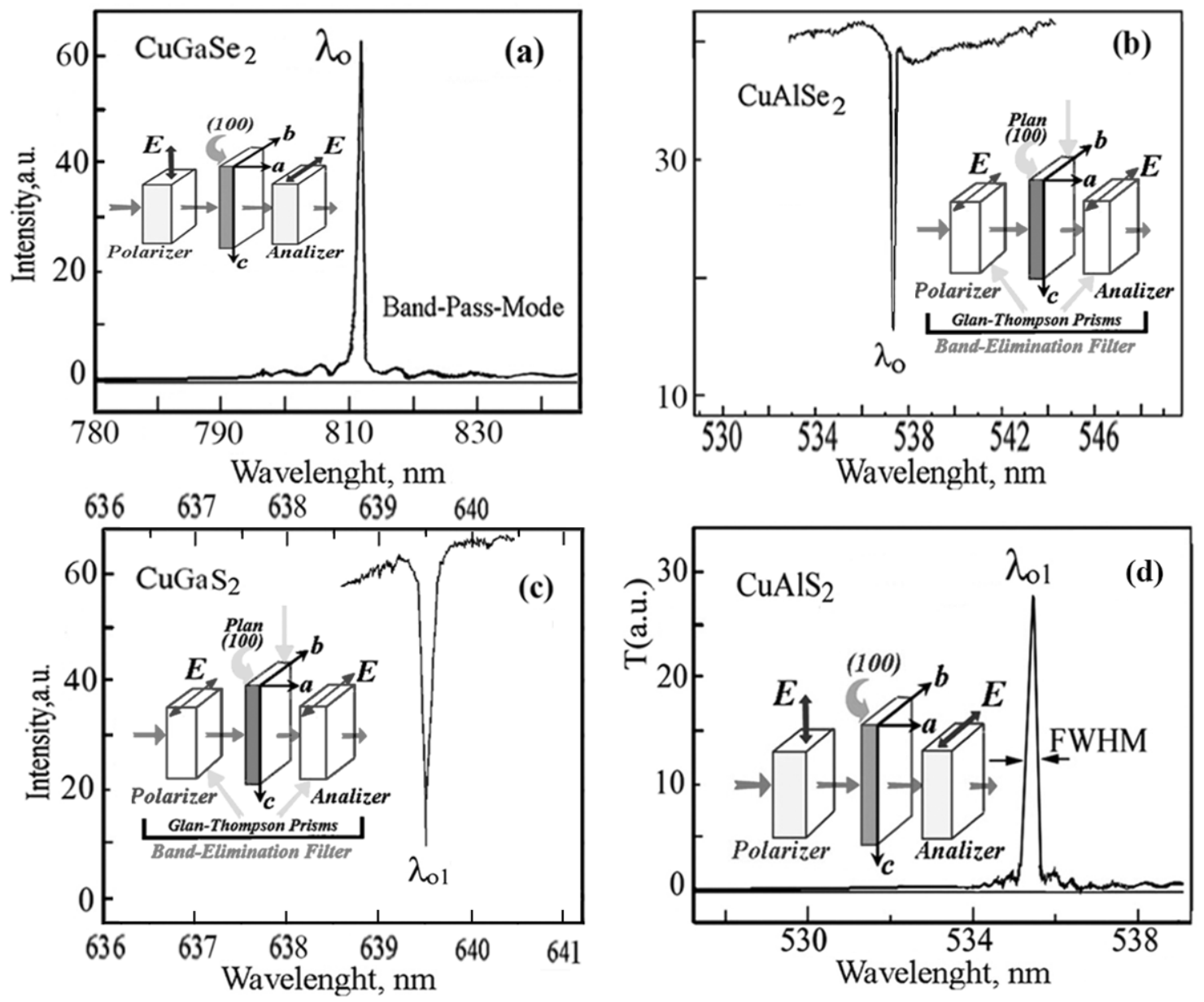

Fig. 5. Band-pass and band-reject filters based on (a) a CuGaSe $\mathrm{Cu}_{2}$ crystal with a thickness of $215 \mu \mathrm{m}$, (b) a $\mathrm{CuAlSe}_{2}$ crystal with a thickness of $270 \mu \mathrm{m}$, (c) a $\mathrm{CuGaS}_{2}$ crystal with a thickness of $235 \mu \mathrm{m}$, and (d) a $\mathrm{CuAlS}_{2}$ crystal with a thickness of $223 \mu \mathrm{m}$.

The transmission in the lateral maximum is determined by the value of $\left[1+(\Delta n / \delta n)^{2}\right]^{-1}$. Therefore, a high rate of increase in the $\Delta n / \delta n$ value with moving away from the isotropic wavelength $\lambda_{0}$ is required for providing a high contrast $[21,22]$. A crystal satisfying the $\delta n \ll \Delta n$ condition and exhibiting a higher rate of change in the dispersion curve $\Delta n$ than that in the dispersion curve $\delta n$ should be used to provide a good filter contrast. The rate of change in the spectral characteristic in one polarization should be higher than the rate of change in the 
orthogonal polarization. The ratio of the intensity in the main maximum to the intensity in the lateral maximum is around 20 for band-pass filters based on $\mathrm{CuGaSe}_{2}$ and $\mathrm{CuAlS}_{2}$ crystals shown in Fig. 5a and Fig. 5d, respectively.

\section{Conclusions}

The results of this study have shown that analyzing the interference bands in the transmission or reflectance spectra measured in the polarizer-crystal-analyzer configuration is a more sensitive and efficient method for the determination of birefringence in crystals and for the determination of isotropic wavelengths than the measurement of interference separately in $E \| c$ and $E \perp c$ polarizations. Two types of isotropic points are inherent in $\mathrm{CuGa}_{x} \mathrm{Al}_{1-x} \mathrm{~S}_{2}$ and $\mathrm{CuGa}_{x} \mathrm{Al}_{1-x} \mathrm{Se}_{2}$ crystals according to their spectral position. The isotropic points of the first type are those situated near the absorption edge, while the second type refers to isotropic points situated in the region of crystal transparency. The change in the spectral position of isotropic points situated near the absorption edge with a change in the composition of the solid solution follows the dependence of the bandgap. This factor makes it possible to adjust the spectral position of the isotropic wavelength to the wavelength of laser lines by varying the solid solution composition and construct band-pass and band-reject filters suitable for application in Raman spectroscopy and other applications. The second type of isotropic points, i.e., those from the region of crystal transparency, is also suitable for developing optical filters.

Acknowledgments. This work was financially supported by the National Agency for Research and Development of the Republic of Moldova under grant no. 20.80009.5007.20 and the Horizon-2020 research and innovation program of the European Union (grant no. 810652, NanoMedTwin project).

\section{References}

[1] Maria C. Tamargo, II-VI Semiconductor Materials and Their Applications, CRC Press, Boka Raton, 2002.

[2] M. Isshiki and J. Wang, Wide-Bandgap II-VI Semicondictors: Growth and Properties, in Springer Handbook of Electronic and Photonic Materials, S. Kasap and P. Capper, Eds., Springer Handbooks, Springer, Cham, 2017.

[3] P. Yeh, Opt. Commun. 35, 15 (1980).

[4] T. Yamomoto, H. Takehara, H. Horinaka, and T. Miyauchi, Jpn. J. Appl. Phys. 25, 1397 (1986).

[5] H. Horinaka, H. Sonomura, and T. Miyauchi, Jpn. J. Appl. Phys. 24, 463 (1985).

[6] J. F. Lotspeich, R.R. Stephens, and D. M. Henderson, IEEE J. Quantum Electron. QE-18, 1253 (1982).

[7] N. Yamamoto, H. Horinaka, Y. Cho, and H. Hamaguchi, Anal. Sci. 7, 581 (1991).

[8] H. Horinaka, N. Yamamoto, and H. Hamaguchi, Appl. Spectrosc. 46, 379 (1992).

[9] H. Horinaka and N. Yamamoto, Proc. SPIE 1319, 592 (1990).

[10] M. Susaki, N. Yamamoto, H. Horinaka, W. Z. Huang, and Y. Cho, Jpn. J. Appl. Phys. 33, 1561 (1994).

[11] M. G. Panthani, V. Akhavan, B. Goodfellow, J. P. Schmidtke, L. Dunn, A. Dodabalapur, P. F. Barbara, and B. A. Korgel, J. Am. Chem. Soc. 130 (49), 16770 (2008). 
[12] I. Repins, M. A. Contreras, B. Egaas, C. DeHart, J. Scharf, C. L. Perkins, B. To, and R. Noufi, Prog. Photovoltaics 16, 235 (2008).

[13] Q.-T. Xu, Z.-D. Sun, Y. Chi, H.-G. Xue, and S.-P. Guo, J. Mater. Chem. C 7, 11752 (2019).

[14] D. S. Chemla, P. J. Kupecek, D. S. Robertson, and R. C. Smith, Opt. Commun. 3, 29 (1971).

[15] G. C. Catella and D. Burlage, MRS Bull. 23, 28 (1998).

[16] J. H. Kim and H. Yang, Chem. Mater. 28, 6329 (2016).

[17] B. Chen, N. Pradhan, and H. Zhong, J. Phys. Chem. Lett. 9, 435 (2018).

[18] X. B. Fan, S. Yu, F. Zhan, Z. J. Li, Y. J. Gao, X. B Li, L. P. Zhang, Y. Tao, C. H. Tung, and L. Z. Wu, ChemSusChem 10, 4833 (2017).

[19] N. Guijarro, M. S. Prevot, X. Yu, X. A. Jeanbourquin, P. Bornoz, W. Bouree, M. Johnson, F. Le Formal, and K. A. Sivula, Adv. Energy Mater. 6, 1501949 (2016).

[20] H. Horinaka, K. Tomii, H. Sonomura, and T. Miyauchi, Jpn. J. Appl. Phys. 24, 755 (1985).

[21] N. Syrbu, A. Dorogan, V. Ursaki, I. Stramov, and I. M. Tiginyanu, Opt. Commun. 284, 3552 (2011).

[22] N. N. Syrbu, A. V. Dorogan, A. Masnik, and V. V. Ursaki, J. Opt. 13, 035703 (2011). 